\title{
Size at sexual maturity and seasonal reproductive activity of the Caribbean spiny lobster Panulirus argus
}

\author{
Nicole A. M. Atherley ${ }^{1,2, *}$, Michelle M. Dennis ${ }^{1,3}$, Donald C. Behringer ${ }^{4,5}$, \\ Mark A. Freeman ${ }^{1}$ \\ ${ }^{1}$ Ross University School of Veterinary Medicine, West Farm, Basseterre, Saint Kitts and Nevis, West Indies \\ ${ }^{2}$ Caribaea Initiative, Université des Antilles, Pointe-á-Pitre, Guadeloupe \\ ${ }^{3}$ Department of Biomedical and Diagnostic Sciences, University of Tennessee College of Veterinary Medicine, Knoxville, \\ TN 37996, USA \\ ${ }^{4}$ Fisheries and Aquatic Sciences, University of Florida, Gainesville, FL 32653, USA \\ ${ }^{5}$ Emerging Pathogens Institute, University of Florida, Gainesville, FL 32611, USA
}

\begin{abstract}
The Caribbean spiny lobster Panulirus argus, a long-lived decapod crustacean, is fished throughout its geographical range and generates close to 1 billion US dollars annually. Fisheries across this range are fully- or over-exploited, spurring management strategies such as closed seasons and minimum size limitations. The objective of this study was to determine the minimum legal size and appropriate closed season for the lobster population of Saint Kitts and Nevis by assessing and comparing the functional, physiological and morphological determinants of sexual maturity. Such a comparison has never been attempted for this species. Females did not reach functional maturity until $87.8 \mathrm{~mm}$ carapace length (CL) based on the presence of a spermatophore and eggs, but reached morphological maturity based on the presence of ovigerous setae at $72.5 \mathrm{~mm}$ CL. Physiological maturity was intermediate at $82.8 \mathrm{~mm}$ CL. Determinants of functional maturity overestimate the size at sexual maturity, while the presence of ovigerous setae underestimates it. The gonadosomatic index, a reliable method of assessing physiological maturity in female $P$. argus, can be used to monitor changes in reproductive activity in both males and females. Gross assessment of the ovary may be used to determine size at physiological maturity, and functional maturity can be used to calculate peak periods of reproduction. The peak physiological and functional maturity for $P$. argus occurs from March to May. As a result, we propose a closed season from March to June and suggest assessment of reproductive dynamics in order to determine minimum legal size for harvesting $P$. argus.
\end{abstract}

KEY WORDS: Fisheries · Size at maturity $\cdot$ Closed season $\cdot$ Gonadosomatic index $\cdot$ Histology

\section{INTRODUCTION}

The Caribbean spiny lobster Panulirus argus (Latreille, 1804) is a decapod crustacean in the family Palinuridae. It is a long-lived sub-tropical and tropical species with a range that extends from North Carolina (USA) and Bermuda to northeastern Brazil (Holthius 1991). Genetic analyses led to the discov-

*Corresponding author: nicoleatherley@hotmail.com ery of a subspecies, $P$. argus westonii, in Brazil (Sarver et al. 1998), but this has since been described as a new species, P. meripurpuratus (Giraldes \& Smyth 2016). P. argus has a complex life cycle which includes coral reefs (adults), shallow vegetated habitats (juveniles) and the pelagic zone of the open ocean (phyllosoma larvae and post-larvae). During the 5-7 mo pelagic stage, phyllosomata are trans-

() The authors 2021. Open Access under Creative Commons by Attribution Licence. Use, distribution and reproduction are unrestricted. Authors and original publication must be credited. 
ported long distances by ocean currents and often settle into shallow, nearshore habitats hundreds of kilometers away from their spawning site (Butler et al. 2011a). The long-distance connectivity between populations is important to consider when constructing a regional effort in the management and control of the lobster fishery.

$P$. argus populations are declining, and some are over-exploited (Butler et al. 2011b, FAO 2019). Approximately $39244 \mathrm{t}$ were landed in 2016 throughout the geographical range, with the main producers being Cuba, the Bahamas and Nicaragua (FAO/ WECAFC 2018). The product is mainly sold to international markets in Europe and Asia, with some sold to support local tourism markets. Saint Kitts and Nevis, in the northeastern Leeward Islands of the Caribbean region, and our test location, generated approximately $15 \mathrm{t}$ in the same year (Pereira \& Josupeit 2017).

Management and conservation measures are required to prevent overfishing and improve reproductive success of commercially important species. However, to devise the proper fishery regulations with the goal of reproductive success and sustainable fisheries, we must thoroughly understand the reproductive cycle of this species. Presently, many countries have implemented reproductive-based regulations on $P$. argus fisheries using recommendations by organizations such as the Caribbean Regional Fisheries Mechanism (CRFM) and the Western Central Atlantic Fishery Commission (WECAFC) (FAO 2019). Fishery regulations exist in all territories in which $P$. argus is fished and include minimum landing sizes and closed seasons, which typically coincide with reproductive maturity and reproductive periods, respectively (FAO 2001, CRFM 2008, Cruz \& Bertelsen 2009). Other management options include restrictions on the capturing or holding of lobsters that are molting (soft-bodied lobsters) or carrying eggs (CRFM 2011). Countries such as Nicaragua and Antigua and Barbuda also prohibit the landing of females with intact spermatophores (FAO 2014). Presently, Saint Kitts and Nevis prohibits the landing of ovigerous females and lobsters smaller than $95 \mathrm{~mm}$ carapace length (CL), but does not enforce a closed season (Wilkin et al. 1986). Some countries, including Belize and Mexico, also employ other management tools including no-take marine protected areas (Truelove et al. 2015, Tewfik et al. 2020).

Knowledge of the size or age at sexual maturation is important for managing a species for harvest and reproduction. Age has been assessed by quantifying the age-associated accumulation of neurolipofuscin
(Maxwell et al. 2007, 2009) and more recently by counting growth bands which are present in the hardened structures of the gastric mill (Gnanalingam et al. 2019). This generated information allows for the development of minimum legal size and other fishery regulations, which often aim to allow an organism to reproduce at least once before being harvested. The minimum legal size should therefore be equal to or larger than the determined size at sexual maturity.

The size at sexual maturity is typically defined as the minimum size at which $50 \%$ of the individuals are sexually mature (Little \& Watson 2003). Maturity is traditionally calculated in female decapods, and can be based on determinants of physiological maturity or functional maturity (Kizhakudan et al. 2019). Physiological maturity in spiny lobsters is characterized by the maturity of the gonads and the ability to produce mature ova or sperm. In females, this is assessed by the color and histological analysis of the gonads. Functional maturity refers to the development of external physical (secondary) characteristics which facilitate successful mating between the male and female members of the same species, such as a black spermatophore on the sternum, eggs deposited on the abdomen and the length of setal hairs (morphological parameter) in females (Gregory \& Labisky 1981, Goñi et al. 2003, Kulmiye et al. 2006). Setal hairs located on the pleopods elongate and function to hold eggs in place on the abdomen while they develop (Gregory \& Labisky 1981, Melville-Smith \& de Lestang 2005).

Histological examination of gonads is the most reliable, albeit invasive, method for assessing the maturity of spiny lobsters (Kizhakudan et al. 2019). However, studies on female spiny lobsters have traditionally used more convenient, non-invasive methods, based on gross assessment of ovaries (color and size), egg-bearing status or the evidence of mating (e.g. spermatophore or 'tarspot') (Munro 1974, Jayakody 1989, Pollock 1995, Melville-Smith \& de Lestang 2006, Horsford et al. 2014). In spiny lobsters, changes in the color of ovaries can be used to predict 4 general histological stages of oocyte development: immature, beginning of maturation, middle of maturation and fully mature (Mota Alves \& Tome 1965, Buesa \& Mota Alves 1971, Minagawa \& Sano 1997, Dávila et al. 2009a). While these color changes can be assessed non-invasively by viewing the ovary through the membrane between the cephalothorax and the abdomen (Melville-Smith \& de Lestang 2005), this method alone may not be reliable. Ovarian development and maturity are best conducted in conjunction with histological analysis (Juinio 1987, 
Goñi et al. 2003, Melville-Smith \& de Lestang 2005, Kulmiye et al. 2006). A color scale was developed to provide information on ovarian maturation in P. argus (Buesa \& Mota Alves 1971), while histological description of gonadal development was also reported (Mota Alves \& Tome 1965, Dávila et al. 2009a,b), although there has been no in-depth comparison between color and histology.

In decapods, size at sexual maturity may change over time and therefore should be periodically reassessed to make appropriate adjustments to the minimum legal size (Öndes et al. 2017). Intensive fishing pressure or environmental factors such as rising seawater temperatures and changes in food availability can affect the size at maturity, but it is not always clear which factor is responsible (Landers et al. 2001, Linnane et al. 2008, Tu et al. 2018). For example, over the past $10-80 \mathrm{yr}$, the size at maturity of American lobster Homarus americanus females has become $30 \%$ smaller (Le Bris et al. 2017, Haarr et al. 2018). It is possible that there is a level of genetic adaptation in response to increased sea temperature where a smaller size at maturity is favorable (Le Bris et al. 2017). The size at sexual maturity of the southern rock lobster Jasus edwardsii has also changed according to water temperature between 1991 and 2015 (McLeay et al. 2019). Temperature is an important influence which mediates physiological factors that drive processes such as reproduction and growth (FAO/WECAFC 2018). Thus, the reduction in size at maturity is likely a response to an increase in water temperature, and possibly other factors (Le Bris et al. 2017, Haarr et al. 2018). Decreased size at maturity can also be explained by populations being subject to high exploitation, which removes organisms with genes for a larger size at maturity (above the legal size) before they can reproduce at least once. This leaves most of the reproduction in the population to those organisms which reproduce at a smaller size (below the legal size), thereby selecting for a population with a smaller size at maturity. This outcome was demonstrated by the attempted control of invasive populations of the North American signal crayfish Pacifastacus leniusculus in Europe. It was reported that high-effort removal, via trapping larger individuals, of this species from freshwater habitats in the UK resulted in the remaining population reaching sexual maturity at a smaller size (Freeman et al. 2010). The size at sexual maturity for $P$. argus varies according to geographic region (Cruz \& Bertelsen 2009, Baeza et al. 2016), potentially explained by variations in environmental factors (Little \& Watson 2003, 2005).
Gonadal development has been described in detail at the gross and microscopic levels for $P$. argus from Brazil (Mota Alves \& Tome 1965) and Cuba (Dávila et al. 2009a,b), and for the spiny lobster species P. japonicus and P. penicillatus (Juinio 1987, Minagawa \& Sano 1997). The size at maturity of $P$. argus from Belize has been assessed using determinants such as setal length and pleopodal size (Tewfik et al. 2020). Without using a histological method to assess size at physiological maturity in $P$. argus, it is unclear how accurately these other methods determine this parameter in the species. To our knowledge, no studies estimating size at sexual maturity in female $P$. argus have used gross and histological assessment of the ovaries, but instead have used determinants of functional maturity such as presence of a spermatophore or eggs.

Closed season designations are typically based on studies which define the seasonal reproductive activity of a species (FAO 2001, Arendse et al. 2007). Reproductive activity is usually assessed by monitoring the proportion of females with a spermatophore or eggs (Bianchini et al. 1998, Briones-Fourzán \& Contreras-Ortiz 1999, Cruz \& Bertelsen 2009). This parameter has been determined using histological methods in spiny lobster species such as P. penicillatus (Juinio 1987). The gonadosomatic index (GSI) is one of the most accurate means of assessing changes in reproductive activity and has been used for determining such changes in the blue swimmer crab Portunus pelagicus and the spiny lobsters Panulirus japonicus and P. inflatus (Minagawa 1999, de Lestang et al. 2003, Pérez-González et al. 2009, Sabrah et al. 2017). GSI is determined by the weight of gonads relative to CL and is based on the assumption of increasing gonadal weight caused by yolk accumulation in oocytes during maturation (Minagawa \& Sano 1997), thus reflecting the histological changes. This method is less expensive than histological analyses (Flores et al. 2015).

The $95 \mathrm{~mm}$ CL minimum legal size for the lobster fishery in Saint Kitts was established in the 1980s based on recommendations from the Food and Agriculture Organization and the Organization of Eastern Caribbean States (OECS) (Wilkin et al. 1986). According to Horsford et al. (2014), this recommended size requirement, based on the size at which $50 \%$ of the females were functionally mature, was the finding of Munro (1974) in his assessment of lobsters in Jamaica. The current management strategies for the Eastern Caribbean are not presently based on research from this region. Moreover, regulations are based on research conducted decades ago, emphasizing the need for more recent representative assessment. No studies 
have used histological analyses or GSI to assess seasonality of reproduction for P. argus. However, Cavalcante Soares (1990) monitored reproductive activity in Brazil by calculating mean ovarian weight per month. This method of monitoring reproductive activity may be prone to some error, since it does not take into account the size of the lobster being assessed.

Here we aimed to compare the functional, physiological and morphological determinants of sexual maturity in female $P$. argus and assess their use in establishing size at sexual maturity. Another aim was to validate the GSI as a tool to determine and monitor seasonal reproductive activity in male and female $P$. argus. Results from this study are expected to more accurately guide management practices for the species throughout its range, and provide support for updating minimum legal size and proposing a closed season for P. argus on Saint Kitts and Nevis.

\section{MATERIALS AND METHODS}

\subsection{Sample collection}

All lobsters were sourced from fishermen across the islands of Saint Kitts and Nevis $\left(17^{\circ} 15^{\prime} \mathrm{N}, 62^{\circ} 42^{\prime} \mathrm{W}\right)$ at the main landing sites: Dieppe Bay in the north, Basseterre in the south, and Old Road in the middle of the island of Saint Kitts. The lobsters were captured in traps baited with cowhide. At least 4 female lobsters were sampled per month from August 2017 to April 2019, with the exception of March 2018 (no samples collected). Lobsters (166 females and 147 males) were selected to ensure a sample population with a wide size range (66-157 mm CL). Small (presumably juvenile) lobsters ranged from $50-79 \mathrm{~mm}$ $\mathrm{CL}$, while larger (presumably adult) lobsters ranged from 80-157 mm CL. A permit was obtained from the Department of Marine Resources (DMR), a department of the Government of Saint Christopher (Kitts) and Nevis, to allow us to collect samples from lobsters smaller than $95 \mathrm{~mm} \mathrm{CL}$.

\subsection{Postmortem examination and calculation of GSI}

Live lobsters obtained from fishermen were anesthetized and euthanized within $2 \mathrm{~h}$ of collection (Atherley et al. 2020). After euthanasia, each lobster was blotted dry with a paper towel and weighed. CL, i.e. the distance from between the rostral horns to the posterior dorsal end of the carapace, was measured along the mid-dorsal line with a pair of Vernier calipers to the nearest $0.1 \mathrm{~mm}$. The cephalothorax of all lobsters was opened and the gonads removed intact and weighed to the nearest gram. The color and appearance of each ovary was recorded before being excised completely and weighed to the nearest gram. Gonadal weight (testes and ovaries) was used to calculate the GSI (Minagawa \& Sano 1997): GSI = gonad weight $\left.(\mathrm{g}) \times 100000 / \mathrm{CL}^{3}\right)$. For each sex, the mean GSI per month was calculated and the months were combined into 4 groups to loosely coincide with seasons observed in temperate climates. Additionally, the peak months of functional maturity were determined by monitoring the proportion of functionally mature females (ovigerous or possessing a spermatophore) over the same time period.

The determination of gonadal stage in this study is consistent with that described for Panulirus argus and other spiny lobster species (Silva \& Da CruzLandim 2006, Dávila et al. 2009a,b), including $P$. penicillatus (Juinio 1987, Chang et al. 2007), P. laevicauda and $P$. echinatus (Silva \& Da Cruz-Landim 2006), and P. japonicus (Minagawa \& Sano 1997). As maturation progresses from the immature to the spawning-capable stage, the size of the ovary increases to the point where it occupies much of the cephalothorax and the posterior lobes extend into the abdomen. A spawning-capable ovary is very delicate at this point and great care must be taken when excising the organ for further study. Indicators of functional maturity in females were recorded as the presence of a spermatophore or the presence of eggs. Sexual maturity in females was also assessed by measuring the setal hairs on the pleopods. Setal hair length was measured to the nearest millimeter using digital calipers and was used to classify maturity according to the scheme of Gregory \& Labisky (1981): undeveloped $(0-3 \mathrm{~mm})$, intermediate (4$8 \mathrm{~mm}$ ) and ovigerous (9-13 mm). Females with setae over $13 \mathrm{~mm}$ were also considered ovigerous. Using this feature, mature females are defined as those with ovigerous setae.

\subsection{Histological preparation and maturity assessment}

Histological assessments were performed on females only. For each individual, an approximately $3 \mathrm{~mm}^{3}$ section of ovary was excised and immediately placed in Davidson's seawater fixative and held therein for at least $48 \mathrm{~h}$ before processing tissue for histological preparation. Fixed tissues were placed in cassettes, embedded in paraffin and sectioned at 
$4 \mu \mathrm{m}$ thickness. Prepared histological sections were stained with hematoxylin and eosin (H\&E) and observed under an Olympus CX31 compound microscope at $40 \times$ magnification. Photographs and measurements were taken using the Olympus cellSens Imaging software. Each ovary was then assessed histologically to characterize stage of gonadal development and was classified according to a scale based on studies conducted on P. japonicus, $P$. argus and $P$. inflatus (Riveros-Celis 1972, MacFarlane \& Moore 1986, Minagawa \& Sano 1997, Dávila et al. 2009a, Pérez-González et al. 2009). Because the terminology used for reproductive developmental stages in crustaceans is inconsistent (MacFarlane \& Moore 1986, Juinio 1987, Dávila et al. 2009a, Pérez-González et al. 2009, Thangaraja \& Radhakrishnan 2017, ArcosOrtega et al. 2019), we used histological features of gonadal development previously described for crustaceans (Joshi \& Khanna 1982, Bell \& Lightner 1988, Silva \& Da Cruz-Landim 2006) while applying standardized terminology adopted from Brown-Peterson et al. (2011): Stage 1: immature; Stage 2: developing; Stage 3: spawning capable; Stage 4: regressing; Stage 5: regenerating.

\subsection{Data analysis}

The mean wet weight and CL were compared between males $(n=147)$ and females $(n=164)$ using the Mann-Whitney test. All other comparisons of mean CL were done using Student's $t$-test. The sizes at physiological, functional and morphological maturity in females were each estimated using the 'sizeMat' package (version 1.1.0) in the RStudio statistical software (version 1.1.463), $\mathrm{R}$ version 3.6.3.

The size at sexual maturity in females was computed using the equation ( $\mathrm{R}$ Core Team 2020):

$$
y=1 /[1+\exp -(a+b \times x)]
$$

In this logistic model equation, $y$ is the probability of a female being mature at a particular $C L, x$. The intercept $(a)$ and the slope $(b)$ are estimated parameters.

In $\mathrm{R}$, physiologically mature females were each put into $5 \mathrm{~mm}$ bins and the data fitted to the above equation; 'immature' was denoted by ' 0 ' and mature by ' 1 ,' where a mature ovary is developing, spawning capable, regressing or regenerating. Three separate calculations of size at physiological maturity were performed using the following parameters of physiological maturity: (1) a combination of gross appearance (color) and histological appearance (by microscopic analysis) of the ovaries examined (mature by either gross or histological analysis and mature by both analyses); (2) histological assessment alone; and (3) gross assessment alone. When calculating the size at functional maturity, the value '1,' denoting maturity, is given to individuals with a spermatophore (tarspot) on the ventral thorax, the presence of eggs on the abdomen, or both, while ' 0 ' denotes an immature individual. Functional maturity is therefore based on evidence of mating and spawning. Size at morphological maturity, based on setal length, was calculated by using the 'MorphMature' feature of the 'sizeMat' package in RStudio, where setal length and CL were allometric variables. The 'sizeMat' analysis package separates individuals into 2 groups: juveniles and adults.

The size (length) at which $50 \%$ of females are mature $\left(L_{50}\right)$ was then calculated using the equation:

$$
\mathrm{L}_{50}=-a / b
$$

\section{RESULTS}

\subsection{Sample population}

The sample population consisted of 166 females (29 juveniles and 137 adults) and 147 males (11 juveniles and 136 adults), and of these, 47 females and 74 males were smaller than the minimum legal harvest size of $95 \mathrm{~mm}$ CL. The mean CL $( \pm \mathrm{SD})$ of males $(97.04 \pm$ $14.87 \mathrm{~mm}$ ) in the sample population was significantly larger than that of the females $(89.53 \pm 12.32 \mathrm{~mm} z=$ $-5.183, p<0.00001)$. There was also a significant difference in their mean weight (males: $775.12 \pm 320.49 \mathrm{~g}$, females: $664.29 \pm 288.21 \mathrm{~g} ; z=-3.972, \mathrm{p}=0.00008$ ), further supporting sexual dimorphism in the species.

The CL of the smallest ovigerous female was $81 \mathrm{~mm}$, and the smallest female carrying a spermatophore was $75 \mathrm{~mm}$. Of the 20 ovigerous females examined grossly and histologically for physiological maturity, $35 \%(n=7)$ had regenerating ovaries while $25 \%(n=$ $5)$ were at the regressing stage of gonadal development. The ovaries of $40 \%(n=8)$ ovigerous females were undergoing maturation; of these, developing and spawning-capable ovaries were observed in $20 \%(n=4)$ females in each case.

\subsection{Morphological and histological descriptions of ovarian tissue}

The Panulirus argus ovary assumes an H-shape, where 2 vertical lobes located in the cephalothorax, dorsal to the lobes of the hepatopancreas, are bridged 


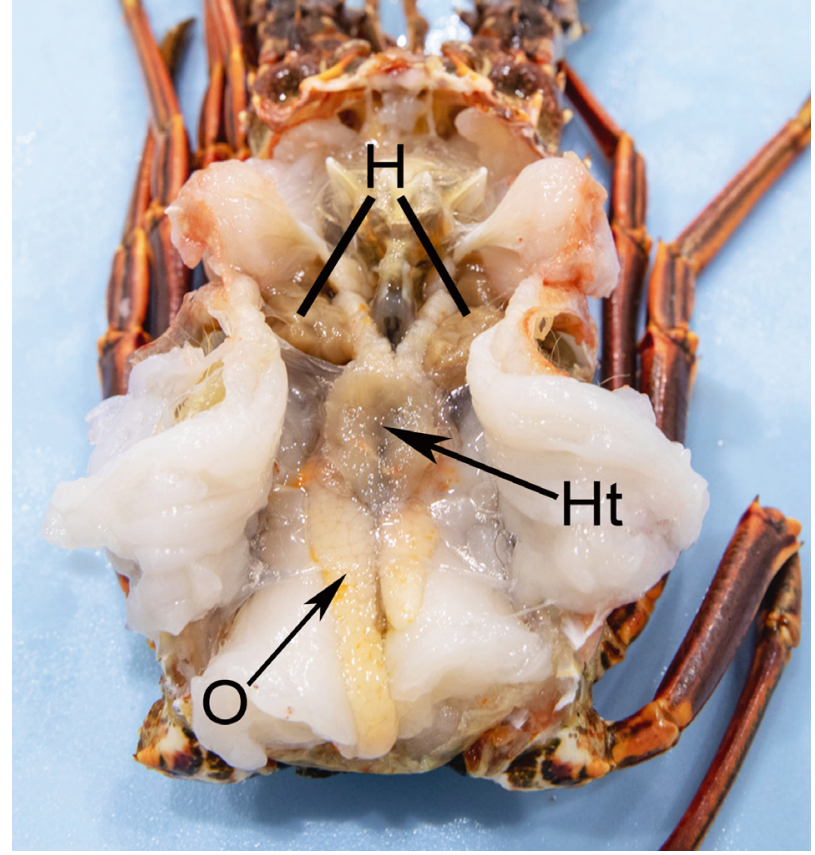

Fig. 1. Location of the gonad (ovary, O) of Panulirus argus in the viscera of the cephalothorax. The ovary lies ventral to the heart $(\mathrm{Ht})$ and dorsal to the hepatopancreas $(\mathrm{H})$

just below the heart (Fig. 1) (Atherley et al. 2020). Each lobe is connected to a gonopore (or genital pore) located at the base of each third walking leg, through which mature ova are extruded. Observed color of each ovary was characterized as follows: immature $=$ white $($ Fig. 2A), developing = yellow to orange (Fig. 2B,C), spawning capable = bright orange (Fig. 2D), regressing $=$ cream with regions of orange (Fig. 2E) and regenerating = cream (Minagawa \& Sano 1997)(Fig. 2F).

Histological features of ovarian maturation were typical of those previously described for crustaceans where the immature ovary consisted mainly of basophilic germ cells (oogonia) and pre-vitellogenic oocytes (Fig. 3A). In the developing ovary, primary and secondary vitellogenic oocytes were more numerous than pre-vitellogenic oocytes (Fig. 3B). Primary vitellogenic oocytes were distinguished by increasing size and the presence of cytoplasmic vacuolation, eosinophilia and yolk granules (Fig. 3C). A spawning-capable ovary consisted mainly of large mature ova. The ova were so large that the cells were tightly packed and lost their defined spherical shape (Fig. 3D). In the regressing ovary, some remnant ova were observed, and the ovarian wall extended into the ovary (Fig. 3E). During the regenerating stage, remnant ova undergo atresia (Fig. 3F).

\subsection{Size at functional, physiological and morphological maturity (females)}

Assessment of 166 females revealed $51 \%(n=85)$ were functionally mature based on the presence of eggs and a spermatophore. The mean \pm SD CL of functionally mature females $(95.7 \pm 10.8)$ was significantly higher $(p<0.00001)$ than those not functionally mature $(88.7 \pm 12.3)$. The mean CL of females with ovigerous setae $(90.5 \pm 10.4)$ was significantly larger than females with undeveloped setal hairs $(78.5 \pm 6.6 ; t=4.8, \mathrm{p}<0.0001, \mathrm{n}=19$; Table 1$)$.

Gross and histological examination of ovarian development $(\mathrm{n}=162)$, revealed that $105(64.8 \%$; 95\% CI 56.9-72.1\%) were physiologically mature (Table 1). From this sample size, the size at onset of physiological maturity determined from a combination of gross and histological assessment of ovarian maturity was $80.8 \mathrm{~mm} \mathrm{CL}\left(\mathrm{r}^{2}=0.2, \mathrm{CI}: 68-84.1 \mathrm{~cm}\right)$. The size at physiological maturity based on histological assessment was $77.9 \mathrm{~mm} \mathrm{CL}\left(\mathrm{r}^{2}=0.2\right.$, CI 65.1 $81.7 \mathrm{~cm}, \mathrm{n}=155$ ) and based on gross assessment of ovarian maturity was $82.8 \mathrm{~mm} \mathrm{CL}\left(\mathrm{r}^{2}=0.53\right.$, CI $80.7-$ $84.5 \mathrm{~cm}, \mathrm{n}=160$ ). The functional maturity was determined to be $87.8 \mathrm{~mm} \mathrm{CL}\left(\mathrm{r}^{2}=0.36\right.$, CI 85.8 to $91.3, \mathrm{n}=$ 160). The size at maturity of females based on development of ovigerous setae was $72.5 \mathrm{~mm} \mathrm{CL}\left(\mathrm{r}^{2}=0.2\right.$, CI $40.9-77.8, \mathrm{n}=130$ ). The confidence intervals around the size at physiological maturity overlap for all 3 methods above; therefore, there is no significant difference between the CL of mature lobsters in these groups (Table 1). Conversely, the size at functional maturity of females is statistically larger than the size at physiological maturity (Table 1).

\subsection{GSI and peak months of reproductive activity}

The mean GSI increased during ovarian development of 144 female $P$. argus, and the mean GSI of females with spawning-capable ovaries was 3.84 (Table 2). Females with spawning-capable ovaries were larger than females with immature ovaries. The smallest lobsters with developing and spawning-capable ovaries were 79.7 and $81.5 \mathrm{~mm} \mathrm{CL}$, respectively.

The proportion of spawning-capable ovaries (determined by gross and histological assessment) was highest from March to May 2018 and March to April in 2019 (Fig. 4A). The lowest proportion of spawningcapable ovaries occurred during September to November 2018. The proportion of mature ovaries was over $50 \%$ during all time periods except September to November 2018 (Fig. 4B). 


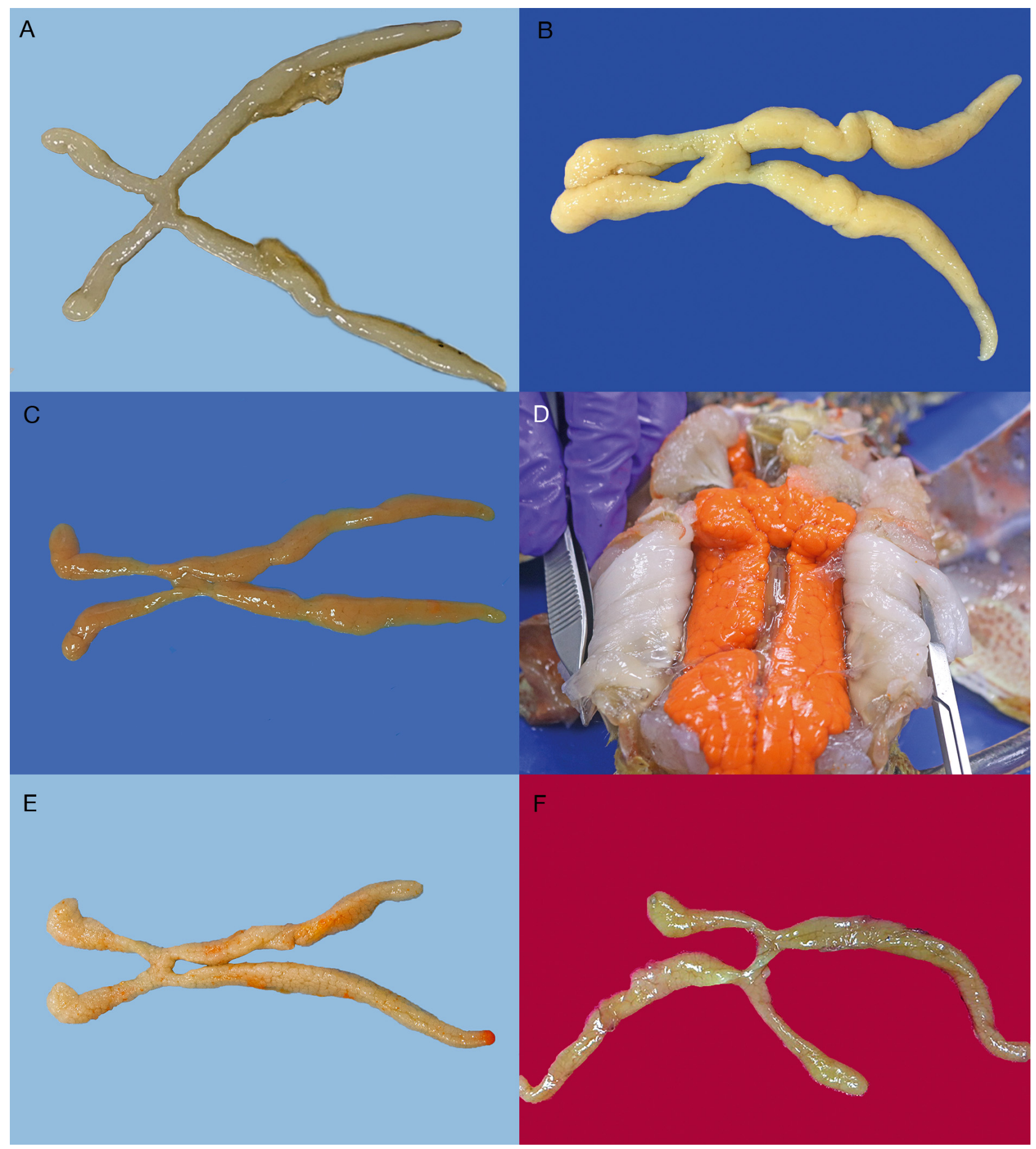

Fig. 2. Gross observation of ovarian development in Panulirus argus. (A) Immature, (B) developing (early), (C) developing (late), (D) spawning capable, (E) regressing, (F) regenerating

The GSI fluctuated seasonally (Fig. 5). Peaks in calculated GSI in male and female $P$. argus were observed particularly from March to May 2018 and March to April 2019 (Fig. 5). The lowest GSI values for both males and females were recorded during
September to November 2018. In comparison, the percentage of functionally mature females fluctuated during the study period. The highest percentage of functionally mature females (based on presence of spermatophore and eggs) was observed March to 


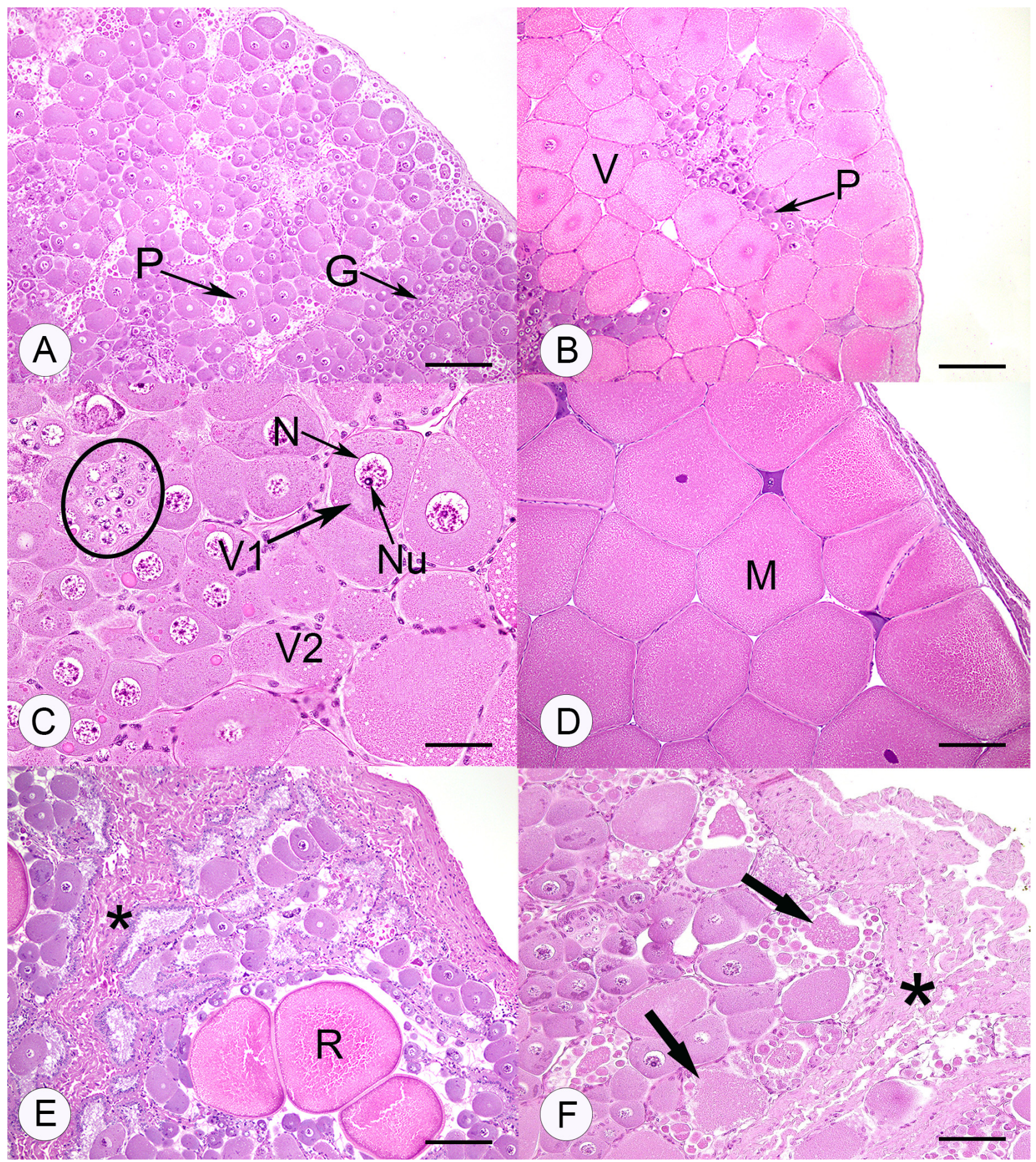

Fig. 3. Histological stage of ovarian development in Panulirus argus. (A) Immature ovary consisting predominantly of basophilic germ cells $(\mathrm{G})$ and pre-vitellogenic (primary) oocytes $(\mathrm{P})$ (scale bar $=90 \mu \mathrm{m})$. (B) Developing ovary consisting of cells at various stages of development, including the pre-vitellogenic oocytes $(\mathrm{P})$ and predominantly vitellogenic oocytes $(\mathrm{V})(\mathrm{scale}$ bar $=90 \mu \mathrm{m})$. (C) Closer view of developing ovary showing distinguishing features of pre-vitellogenic oocytes (circled), primary and secondary vitellogenic secondary oocytes (V1 and V2). The nucleus (N) and nucleolus (Nu) of the primary vitellogenic oocytes (V1) are enlarged and conspicuous, and yolk granules become apparent as maturation progresses to the V2 stage (scale bar $=40 \mu \mathrm{m})$. (D) Spawning-capable ovary with tightly packed and misshapen mature oocytes (M) (scale bar = $90 \mu \mathrm{m}$ ). (E) Regressing ovary with few remnant ova (R) and collapsed connective tissue (asterisk; scale bar $=90 \mu \mathrm{m}$ ). (F) Regenerating ovary with thickened ovarian wall (asterisk) and atretic ova (arrows; scale bar $=90 \mu \mathrm{m})$ 
Table 1. Size (mean \pm SD carapace length, CL, with $95 \%$ CI in parentheses) at sexual maturity of female Panulirus argus determined by assessment of physiological maturity (histological assessment of ovaries only, gross assessment of ovaries and a combination of histological and gross assessment of ovaries), functional maturity (determined by the presence of eggs and a spermatophore) and assessment of morphological maturity determined by the presence of ovigerous setae. Size at maturity was calculated using R software ('sizeMat' package). NA: not applicable

\begin{tabular}{|c|c|c|c|c|}
\hline Maturity status & $\mathrm{N}$ & CL (mm) & Size at maturity CL (mm) & Maturity type \\
\hline Histology only (ovarian maturity) & 155 & $89.2 \pm 11.0(87.5-90.9)$ & $77.9(65.1-84.5)$ & Physiological \\
\hline Immature & 43 & $83.2 \pm 10.8(80-86.4)$ & & \\
\hline Mature (developing to regenerating) & 112 & $91.5 \pm 10.2(89.6-93.4)$ & & \\
\hline Gross only (ovarian maturity) & 160 & $89.1 \pm 11.2(80-86.4)$ & $82.8(80.7-84.5)$ & Physiological \\
\hline Immature (white) & 50 & $80.3 \pm 6.0(78.6-82)$ & & \\
\hline Mature (all other colors) & 110 & $93.3 \pm 10.7(91.3-95.3)$ & & \\
\hline Histological and gross (ovarian maturity) & 162 & $89.3 \pm 11.7(87.5-91.1)$ & $80.8(68-84.1)$ & Physiological \\
\hline Immature & 57 & $83.8 \pm 13.0(80.4-87.2)$ & & \\
\hline Mature (developing to regenerating) & 105 & $92.3 \pm 9.8(90.4-94.2)$ & & \\
\hline Ovigerous status & 165 & $89.5 \pm 12.3(87.6-91.4)$ & NA & Functional \\
\hline Non-ovigerous (immature) & 145 & $88.7 \pm 12.3(86.7-90.7)$ & - & \\
\hline Ovigerous (mature) & 20 & $95.2 \pm 11.0(90.4-100)$ & & \\
\hline Spermatophore status ${ }^{\mathrm{a}}$ & 166 & $89.5 \pm 12.3(87.6-91.4)$ & $87.8(85-90.7)$ & Functional \\
\hline Without spermatophore & 81 & $83.0 \pm 10.4(80.7-85.3)$ & & \\
\hline With spermatophore (mature) & 85 & $95.7 \pm 10.8(93.4-98)$ & & \\
\hline Setal hair length & 130 & $88.2 \pm 10.8(86.3-90.1)$ & $72.5(40.9-77.8)$ & Morphological \\
\hline Undeveloped & 19 & $78.5 \pm 6.6(75.5-81.5)$ & & \\
\hline Intermediate & 20 & $87.2 \pm 10.7(82.5-91.9)$ & & \\
\hline Ovigerous (mature) & 91 & $90.5 \pm 10.4(88.4-92.6)$ & & \\
\hline
\end{tabular}

Table 2. Comparison between gross and histological observations of gonadal development, and gonadosomatic index (GSI \pm SD and $95 \%$ confidence interval) in female Panulirus argus $(\mathrm{n}=144)$ from August 2017 to April 2019. The color of the ovary is based on gross observation while the stage of the ovary is based on a combination of gross and histological observation

\begin{tabular}{|c|c|c|c|}
\hline Stage and color of ovary & $\mathrm{N}$ & $\mathrm{GSI} \pm \mathrm{SD}$ & $95 \% \mathrm{CI}$ \\
\hline Immature (I), white & 47 & $0.25 \pm 0.13$ & $0.211-0.289$ \\
\hline $\begin{array}{l}\text { Developing (II), } \\
\text { yellow to light orange }\end{array}$ & 33 & $0.70 \pm 0.40$ & $0.566-0.834$ \\
\hline $\begin{array}{l}\text { Spawning capable (III), } \\
\text { bright orange }\end{array}$ & 27 & $3.84 \pm 2.19$ & $3.01-4.67$ \\
\hline $\begin{array}{l}\text { Regressing (IV), white } \\
\text { with orange regions }\end{array}$ & 7 & $0.96 \pm 0.56$ & $0.55-1.38$ \\
\hline $\begin{array}{l}\text { Regenerating (V), } \\
\text { off-white }\end{array}$ & 30 & $0.41 \pm 0.20$ & $0.338-0.482$ \\
\hline
\end{tabular}

May in 2018 and March to April 2019. Conversely, the lowest proportions were observed consistently from September to November in 2017 and 2018 (Fig. 6). Peak physiological and functional maturity was thus observed from March to May during the study period, corresponding to the GSI values (Fig. 5).

\section{DISCUSSION}

This is the first study to compare size at onset of sexual maturity in Panulirus argus using 3 complementary methods (gross assessment, histology and GSI) on the same sample population. We used the most accurate methods available, which are also currently being used in studies of other crustacean species such as the red frog crab Ranina ranina and the spiny lobsters $P$. homarus homarus and P. inflatus (Pérez-González et al. 2009, Bayon \& Tito 2012, Thangaraja \& Radhakrishnan 2017). The size at which females present sexual maturity varies according to the specific maturity cues examined. Our data indicate that the onset of physiological maturity precedes the onset of functional maturity. In addition, the size at which $P$. argus reaches functional and physiological maturity is lower than the current minimum legal harvest size (95 mm CL) in Saint Kitts and Nevis. We also show that only using functional maturity cues (i.e. presence of a spermatophore and ovigerous status) overestimates size at maturity, whereas calculating this size based on ovigerous setae underestimates it. The GSI data support the implementation of a closed season in Saint Kitts and Nevis from March to May, the period 


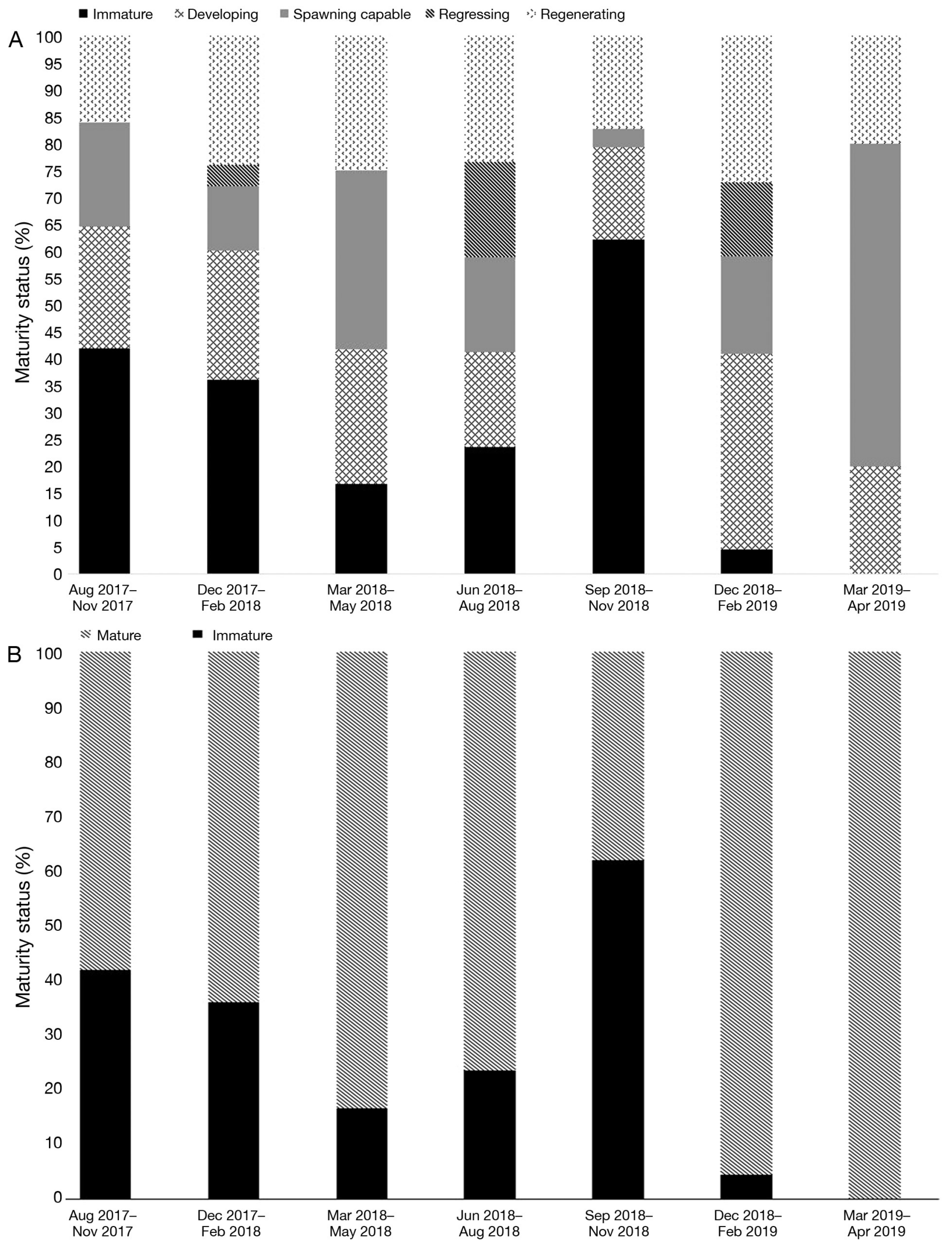

Fig. 4. Histological characterization of gonads in female Panulirus argus (n=162) monitored from August 2017 to April 2019. (A) Percentages of each histological stage of gonadal development. (B) Percentages of histological gonadal maturity (where developing, spawning capable, regressing and regenerating ovaries have been grouped in to the 'Mature' category) 


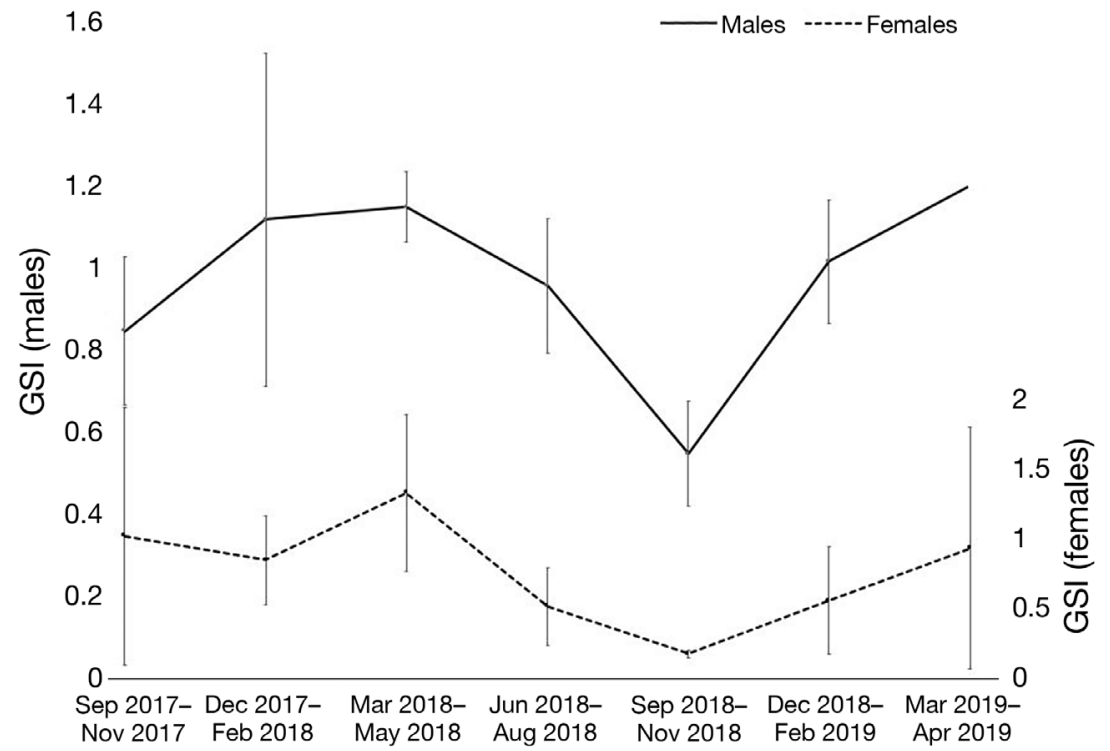

Fig. 5. Gonadosomatic index values (GSI) of male $(\mathrm{n}=143)$ and female $(\mathrm{n}=157)$ Panulirus argus in St. Kitts from September 2017 to April 2019 (bars represent standard deviation)

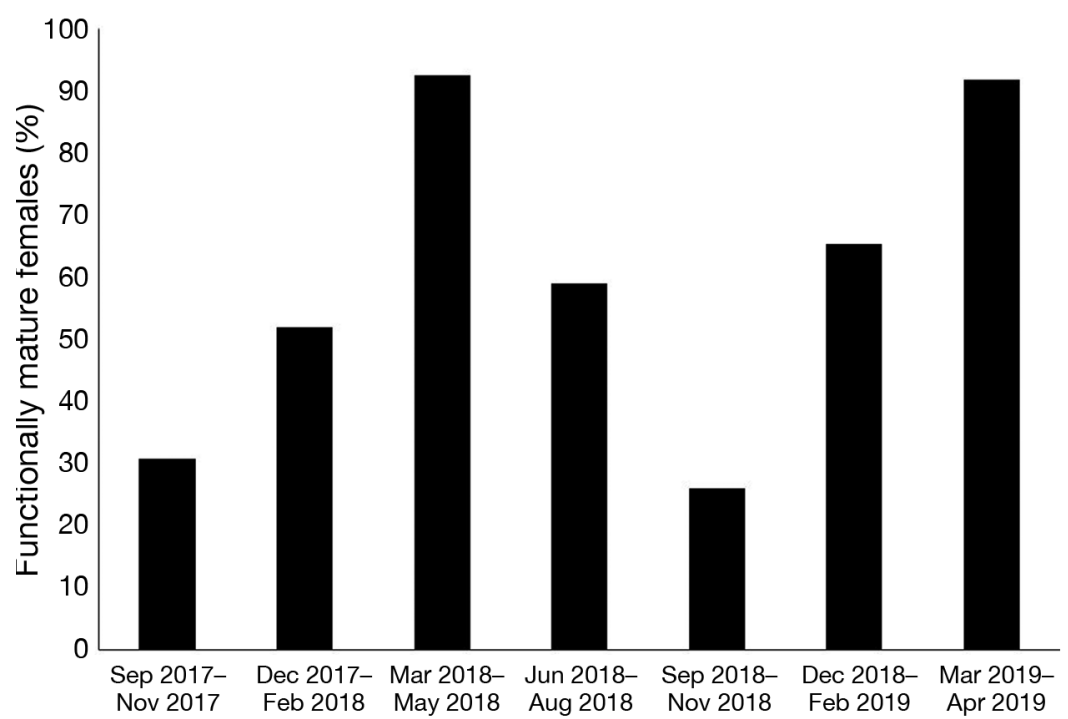

Fig. 6. Percentage of functionally mature Panulirus argus females (i.e. either ovigerous or with a spermatophore) observed in St. Kitts from July 2017 to April 2019

during which the species shows a peak in reproductive activity.

The size at physiological and functional maturity among female $P$. argus lobsters in Saint Kitts was 82.8 and $87.8 \mathrm{~mm} \mathrm{CL}$, respectively. These values were statistically different, indicating that physiological maturity in $P$. argus occurs before functional maturity. Physiological maturity cues may provide more accurate information on the size at sexual maturity in $P$. argus. The data indicate that studies which do not use determinants of physiological maturity may be overestimating the size at sexual maturity, possibly leading to large minimum legal size restrictions. Females physiologically capable of reproducing may, however, become functionally mature at a later stage, after ecdysis and resulting increase in size. If one reduces the minimum legal size at this point, removal of larger females may cause an adaptation resulting in smaller females becoming functionally mature closer to the size at physiological maturity. The size at physiological maturity of $P$. argus in Saint Kitts using gross appearance of the ovary was not significantly different from the value calculated using histological analysis. Therefore, gross assessment of the ovaries of $P$. argus can be used to calculate physiological maturity, although studies on another spiny lobster, P. cygnus, suggest otherwise (Melville-Smith \& de Lestang 2005). This information gives valuable insight on the sequence of maturation in the species being studied. Some crustaceans reach physiological maturity before functional maturity, but this is not the case for all species. For example, female $P$. penicillatus reach physiological maturity before attaining functional maturity (Chang et al. 2007), but female orange mud crabs Scylla olivacea reach physiological and functional maturity at the same carapace width (Waiho et al. 2016). Such studies may aid in determining which characteristics should be used to calculate size at maturity and subsequently implement the appropriate minimum landing size.

Upon further comparison of the cues of sexual maturity, our results show that the development of ovigerous setae occurs before the onset of physiological maturity. This characteristic leads to an underestimation of size at sexual maturity since ovigerous setae seem to develop several molts before ovaries begin to develop. It may therefore not be a reliable parameter for calculation of the minimum legal harvest size for this species. Although maturity is assessed based on the presence of ovigerous setae in 
other spiny lobster species such as Jasus edwardsii, there have been inconsistent results when this parameter is used (Booth 1984, Gardner et al. 2005). While the presence of setae in $J$. edwardsii correlates with mature ovaries, that is not the case in Sagmariasus verreauxi (formerly Jasus verreauxi). Further to this, the development of ovigerous setae in $S$. verreauxi occurs before the onset of functional maturity (Booth 1984), and is consistent with observations in the current study. Based on these observations, calculating size at maturity in $P$. argus using this method is not recommended.

The size at sexual maturity calculated in this study (87.8 $\mathrm{mm} \mathrm{CL}$ ) is lower than the minimum legal size enforced in Saint Kitts and Nevis. Larger females spawn more than once during the mating season, and produce a larger brood comprising larger eggs; thus, larger females are more fecund (Cruz \& Bertelsen 2009, Dávila et al. 2009a). While female size may not affect egg quality and size (Butler et al. 2015), the trend towards reduction in female size nevertheless is of concern since reduced egg production may lead to lower postlarval recruitment rates. Our study focused on size at sexual maturity in females, but based on our data, similar studies should be conducted on males. In commercially exploited crustaceans, the protection of ovigerous females leads to increased fishing pressure on males (Butler et al. 2015). Sexual dimorphism in $P$. argus favors males as the larger counterpart (Holthius 1991), which further explains the increased fishing pressure. The removal of large males from the broodstock has implications on the reproductive systems of crustaceans. Mating success in spiny lobsters such as $P$. japonicus is mediated by size, where larger males are more aggressive and successfully out-compete their smaller counterparts (Hamasaki et al. 2018). Larger male $P$. argus produce larger spermatophores which contain more sperm, thereby increasing fertilization success of female egg clutches (Butler et al. 2011c, 2015). Therefore, the removal of larger males results in females mating with smaller males, reducing reproductive output. Selection of smaller males may be a driving factor for an increase in smaller individuals in the fishing stock, as is reported in the European lobster Homarus gammarus (Sørdalen et al. 2018). Removal of larger individuals from a crustacean population affects mating processes, which include a reduction in size at sexual maturity as reported for signal crayfish (Freeman et al. 2010). Assessments of the size structure and the long-term impact of fishing practices on the mating systems of the wild $P$. argus population need to be conducted to determine whether a given minimum landing size is appropriate.

In their review, Cruz \& Bertelsen (2009) suggested that a minimum legal size of $80 \mathrm{~mm}$ CL should be adopted by all countries in an effort to harmonize management of the species throughout its geographical range. However, $2 P$. argus populations in Florida, from the Florida Keys and Dry Tortugas, were shown to have different size at maturity values. The differences in growth rate and size at maturity was driven by fishing pressure (Dry Tortugas is a no-take marine protected area) and differences in environmental conditions such as temperature and population density (Maxwell et al. 2009). Temperature also affected the size at maturity in the rock lobster $P$. cygnus in Western Australia, further confirming the effects of environmental parameters on reproduction (Melville-Smith et al. 2010). The continued and targeted removal of larger individuals from a crustacean population can affect developmental rates and mating processes in the remaining smaller individuals. Long-term implications can include a marked reduction in size at sexual maturity for some decapods, such as in populations of invasive signal crayfish in Europe (Freeman et al. 2010). Fishing of H. americanus over the past $80 \mathrm{yr}$ has led to the removal of larger adults, and as a result, they now become sexually mature at a smaller size (Le Bris et al. 2017, Haarr et al. 2018). It is possible that this phenomenon is due to increased food availability and less competition for resources that would result if the larger individuals had not been removed. Since fishing pressure, population density and environmental parameters vary across its range, the size at maturity for $P$. argus probably also varies. For example, recent research on size at sexual maturity in Belize revealed that females reach maturity at $86 \mathrm{~mm}$ CL (reported as $70 \mathrm{~mm}$ CL in previous studies), while the minimum legal size is $76 \mathrm{~mm} \mathrm{CL}$ (Tewfik et al. 2020). That study also reported that $P$. argus is overfished in that country, although other management restrictions are in place. This demonstrates the negative impact of employing a minimum legal size which is significantly lower than the size at sexual maturity of the population (Tewfik et al. 2020). A reduction of the minimum legal size in Saint Kitts based on size at physiological maturity (this study) is larger than the minimum legal size adopted in many countries in the $P$. argus range. In addition, the minimum legal size in the USA, Cuba and the Bahamas is smaller than the size at physiological maturity reported in our study (Table 3). We recommend that each territory conducts its own similar study to determine the dynam- 
Table 3. Closed season, size (carapace length, CL) at onset of maturity in female Panulirus argus, including determinants used to classify sexual maturity and corresponding minimum legal landing size across geographical range

\begin{tabular}{|c|c|c|c|c|c|c|}
\hline Country & Closed season & Reference & $\begin{array}{l}\text { CL at sexual } \\
\text { maturity (mm) }\end{array}$ & $\begin{array}{l}\text { Determinants } \\
\text { of maturity }\end{array}$ & $\begin{array}{l}\text { Minimum } \\
\text { legal CL (mm) }\end{array}$ & Reference \\
\hline Antigua $^{a}$ & 1 May - 30 June & $\begin{array}{l}\text { Horsford } \\
\text { et al. }(2014)\end{array}$ & $80-89$ & $\begin{array}{l}\text { Spermatophore } \\
\text { and/or eggs }\end{array}$ & & Peacock (1974) \\
\hline Antigua $^{a}$ & & & $95.7-97.7$ & $\begin{array}{l}\text { Spermatophore } \\
\text { and/or eggs }\end{array}$ & 95 & $\begin{array}{l}\text { Chakalall (1992), Horsford et al. } \\
\text { (2014) }\end{array}$ \\
\hline Bahamas & 1 April - 31 July & $\begin{array}{l}\text { Gascoigne } \\
\text { et al. (2018) }\end{array}$ & & & 82.6 & Gascoigne et al. (2018) \\
\hline Belize & $\begin{array}{l}15 \text { February - } \\
14 \text { June }\end{array}$ & CRFM (2011) & 70 & Setal length & 76 & $\begin{array}{l}\text { FAO (1968), Davis (1975), } \\
\text { Cruz \& Bertelsen (2009) }\end{array}$ \\
\hline Bermuda & $\begin{array}{l}1 \text { April - } \\
31 \text { August }\end{array}$ & $\begin{array}{c}\text { Cruz \& } \\
\text { Bertelsen (2009) }\end{array}$ & 90 & $\begin{array}{l}\text { Spermatophore } \\
\text { and/or eggs }\end{array}$ & 81 & $\begin{array}{l}\text { Sutcliffe (1952), } \\
\text { Evans et al. (1995) }\end{array}$ \\
\hline Bermuda & & & 86 & Spermatophore & 92 & $\begin{array}{l}\text { Evans et al. (1995), } \\
\text { Trott et al. (2002) }\end{array}$ \\
\hline Brazil & $\begin{array}{l}1 \text { January - } \\
30 \text { April }\end{array}$ & $\begin{array}{c}\text { Cruz \& Bertelsen } \\
\text { (2009) }\end{array}$ & & & & \\
\hline Cuba & February-July & $\begin{array}{c}\text { Alzugaray } \\
\text { et al. (2018) }\end{array}$ & $79-81$ & Eggs & 76 & Davis (1975), Puga et al. (2010) \\
\hline Dominican Republic & $\begin{array}{l}1 \text { March - } \\
30 \text { June }\end{array}$ & $\begin{array}{c}\text { Cruz \& Bertelsen } \\
\text { (2009) }\end{array}$ & & & & \\
\hline Dry Tortugas (Florida) & & & $86-95$ & & $86-95$ & Davis (1975) \\
\hline Florida & 1 April - 5 August & CRFM (2008) & & & & \\
\hline Florida Keys & & & $85-90$ & Setal length & 76 & Gregory \& Labisky (1981) \\
\hline Florida Keys & & & 75 & Eggs & & Bertelsen \& Matthews (2001) \\
\hline Grenada & & & & & 90 & CRFM (2008) \\
\hline Haiti & $\begin{array}{l}1 \text { April - } \\
30 \text { September }\end{array}$ & CRFM (2008) & & & & \\
\hline Jamaica & 1 April - 30 June & $\begin{array}{l}\text { Kelly (2003), } \\
\text { Cook-Panton (2015 }\end{array}$ & 5) & Eggs & 76.2 & Munro (1974), Kelly (2003) \\
\hline Saint Kitts and Nevis ${ }^{\mathrm{a}}$ & No closed & season & $\begin{array}{c}82.8,87.8 \\
72.5\end{array}$ & $\begin{array}{l}\text { Physiological, } \\
\text { functional, } \\
\text { morphological }\end{array}$ & 95 & Chakalall (1992), this study \\
\hline Saint Lucia ${ }^{a}$ & $\begin{array}{l}1 \text { May - } \\
31 \text { August }\end{array}$ & $\begin{array}{c}\text { CRFM (2008), } \\
\text { Cruz \& Bertelsen } \\
\text { (2009) }\end{array}$ & & & 95 & Chakalall (1992) \\
\hline Saint Vincent ${ }^{\mathrm{a}}$ & 1 May - 31 August & CRFM (2008) & & & 95 & Chakalall (1992) \\
\hline Turks and Caicos & 1 April - 31 July & CRFM (2008) & & & & \\
\hline USVI and Puerto Rico & & & & & 89 & Bohnsack et al. (1991) \\
\hline
\end{tabular}

ics of their $P$. argus population and update the minimum legal size, if necessary. Implementing a minimum legal size which is based on the size at sexual maturity, however varied, is therefore warranted and could potentially lead to more effective and harmonized management strategies. The decision to reduce the minimum legal size of crustaceans must be carefully considered, since this reduction could potentially affect the future size at sexual maturity of a population.
Analysis of physiological cues (gross and histological) and of the GSI during the study period reveals that peak reproductive activity in female $P$. argus on Saint Kitts consistently occurred from March to May. Peak reproductive activity in males and females coincided and further shows the efficacy of the GSI in determining seasonal reproductive activity in $P$. argus. Lastly, there was harmony between the GSI, histological and gross assessment of ovaries examined, suggesting that the GSI accurately reflects his- 
tological changes in gonadal maturity of $P$. argus females. The efficacy of using the GSI in monitoring reproductive activity has also been shown in studies of female and male P. japonicus (Minagawa \& Sano 1997, Minagawa 1999). For P. argus on Saint Kitts and Nevis, monitoring reproductive activity by GSI or functional characteristics (spermatophores or eggs) was equally effective, so either method can be used. Moreover, the GSI values were useful in distinguishing between immature, developing and spawningcapable stages as was found in other species within the genus Panulirus, including P. japonicus, P. inflatus and P. penicillatus (Juinio 1987, Minagawa \& Higuchi 1997, Pérez-González et al. 2009). However, it was difficult to distinguish between immature and regenerating ovaries using this method, as is the case in other marine species (McPherson et al. 2011).

Considering that eggs take 3-4 wk to mature (Cruz \& Bertelsen 2009), our data indicate that a closed season from March to June is advisable for Saint Kitts and Nevis. Our proposed closed season occurs within the months suggested by Cruz \& Bertelsen (2009), which spans 1 February to 30 June. Further to that, Cruz \& Bertelsen (2009) indicated that the closed season was applicable to all countries in the Western Atlantic. Currently, many countries adopt and enforce varying closed season periods (Table 3). However, since determination of the closed season should be based on the reproductive dynamics of a population, we suggest each territory conduct its own research to this end. This suggestion also takes into consideration the movement of $P$. argus larvae throughout its range. For example, Saint Kitts and Nevis and Saba are considered larval importers while the neighboring islands of Antigua, Guadeloupe and Montserrat are exporters (Kough et al. 2013, Buesa 2018). Saint Kitts and other countries within the Leeward Islands import postlarvae from Venezuela, and export to the Bahamas and Puerto Rico. There is also a low level of self-recruitment in the Leeward Islands (Kough et al. 2013). Regional management strategies therefore need to account for local differences in $P$. argus reproduction, larval migration and postlarval recruitment.

In conclusion, we show size at maturity and peak reproductive activity that differs from prior reports in the region. Our study is the first to simultaneously use GSI and histology, 2 accurate approaches for assessing seasonal changes in the gonads. Our results indicate that gross assessment of ovarian maturity may be used to calculate size at maturity, while the presence of eggs and a spermatophore may be used to determine peak reproduction in female $P$. argus.
Our findings underscore the importance of using locally derived reproductive data for regulatory decision making. In turn, the resulting fishery management protocols must consider effects on other countries by way of larval exportation. Territories lacking recent data are advised to assess their $P$. argus populations using the techniques presented here.

Acknowledgements. This research was jointly funded by Ross University School of Veterinary Medicine and the Caribaea Initiative. We thank the Department of Marine Resources of the government of Saint Kitts and Nevis, which was instrumental in granting special permissions for research on Panulirus argus in Saint Kitts and also facilitated a good relationship with fishermen on the island. We also thank David Hilchie for preparing the histological slides, and pathology technicians including Candita Chapman, Maurice Matthew, and Randel Thompson. We also thank Cleon Bradshaw for his assistance with a crucial photograph included in this manuscript.

\section{LITERATURE CITED}

Arcos-Ortega GF, Serrano-Silvas SR, Rodríguez-Jaramillo C, Acuña-Gómez EP, Schofield-Astorga DC, Olave-Solar CD (2019) Oogenesis of Lithodes santolla: histological and histochemical characterization. Lat Am J Aquat Res 47:480-491

Alzugaray R, Puga R, Pineiro R, de Leon ME, Cobas LS, Morales E (2018) The Caribbean spiny lobster (Panulirus argus) fishery in Cuba: current status, illegal fishing, and environmental variability. Bull Mar Sci: 94:393-408

Arendse CJ, Govender A, Branch GM (2007) Are closed fishing seasons an effective means of increasing reproductive output? A per-recruit simulation using the limpet Cymbula granatina as a case history. Fish Res 85:93-100

Atherley NAM, Freeman MA, Dennis MM (2020) Postmortem examination of the Caribbean spiny lobster (Panulirus argus, Latreille 1804) and pathology in a fishery of the Lesser Antilles. J Invertebr Pathol 175:107453

Baeza JA, Simpson L, Ambrosio LJ, Mora N, Gueron R, Childress MJ (2016) Active parental care, reproductive performance, and a novel egg predator affecting reproductive investment in the Caribbean spiny lobster Panulirus argus. BMC Zool 1:6

Bayon JC, Tito OD (2012) Reproductive biology of the red frog crab, Ranina ranina (Linnaeus, 1758) (Crustacea: Decapoda: Raninidae) from southwestern Mindanao, Philippines. Asian Fish Sci 25:113-123

Bell TA, Lightner DV (1988) A handbook of normal penaeid shrimp histology. World Aquaculture Society, Baton Rouge, LA

Bertelsen RD, Matthews TR (2001) Fecundity dynamics of female spiny lobster (Panulirus argus) in a south Florida fishery and Dry Tortugas National Park sanctuary. Mar Freshw Res 52:1559-1565

*Bianchini ML, Di Stefano L, Ragonese S (1998) Size and age at onset of sexual maturity of female Norway lobster Nephrops norvegicus (Crustacea; Nephropidae) in the Strait of Sicily (Central Mediterranean Sea). Sci Mar 62:151-159

Bohnsack J, Meyers S, Appeldoorn R, Beets J, Matos D, 
Sadovy Y (1991) Stock assessment of spiny lobster, Panulirus argus, in the US Caribbean: final stock assessment and fishery evaluation (SAFE) report for the workshop on spiny lobster resources in the US Caribbean, San Juan, Puerto Rico, September 11-13, 1990, Miami, FL

Booth JD (1984) Size at onset of breeding in female Jasus verreauxi (Decapoda: Palinuridae) in New Zealand. NZ J Mar Freshw Res 18:159-169

* Briones-Fourzán P, Contreras-Ortiz G (1999) Reproduction of the spiny lobster Panulirus guttatus (Decapoda: Palinuridae) on the Caribbean coast of Mexico. J Crustac Biol 19:171-179

Krown-Peterson NJ, Wyanski DM, Saborido-Rey F, Macewicz BJ, Lowerre-Barbieri SK (2011) A standardized terminology for describing reproductive development in fishes. Mar Coast Fish 3:52-70

Buesa RJ (2018) Spiny lobsters fisheries in the Western Central Atlantic (Research Final Report - 27 January 2018). https:// www.researchgate.net/publication/322754555_ Spiny_lobsters_fisheries_in_the_Western_Central_Atlantic _RESEARCH_FINAL_REPORT_-_27_January_2018

Buesa RJ, Mota Alves MI (1971) Escala de colores para el estudio del ciclo reproductoe de la langosta, Panulirus argus (Latreille) en el area del mar Caribe. FAO Fish Rep 71:9-12

Butler MJ IV, Cockcroft A, MacDiarmid A, Wahle R (2011a) Caribbean spiny lobster Panulirus argus. The IUCN Red List of Threatened Species 2011: e.T169976A6697254. https://doi.org/10.2305/IUCN.UK.2011-1.RLTS.T169976 A6697254.en

Butler MJ IV, Paris CB, Goldstein JS, Matsuda H, Cowen RK (2011b) Behavior constrains the dispersal of long-lived spiny lobster larvae. Mar Ecol Prog Ser 422:223-237

Butler MJ IV, Heisig-Mitchell JS, Macdiarmid AD, Swanson RJ (2011c) The effect of male size and spermatophore characteristics on reproduction in the Caribbean spiny lobster, Panulirus argus. Crustac Monogr 15:69-84

Butler MJ, Macdiarmid A, Gnanalingam G (2015) The effect of parental size on spermatophore production, egg quality, fertilization success, and larval characteristics in the Caribbean spiny lobster, Panulirus argus. ICES J Mar Sci 72(Suppl 1):i115-i123

Cavalcante Soares CN (1990) Reproductive season of the Caribbean spiny lobster Panulirus argus in the coastal waters of northern Brazil. Fishbyte 8:27-28

Chakalall B (1992) Fisheries management in the Lesser Antilles. Proc Gulf Caribb Fish Inst 42:294-330

* Chang YJ, Sun CL, Chen Y, Yeh SZ, Chiang WC (2007) Reproductive biology of the spiny lobster, Panulirus penicillatus, in the southeastern coastal waters off Taiwan. Mar Biol 151:553-564

Cook-Panton K (2015) An analysis of puerulus settlement of the Caribbean spiny lobster (Panulirus argus) stock in Jamaica with practical management recommendations. United Nations University Fisheries Training Programme, Iceland [final project]

CRFM (Caribbean Regional Fisheries Mechanism) (2008) A regional overview of spiny lobster (Panulirus argus) resources in CARICOM/CARIFORUM countries. CRFM, Belize City

CRFM (2011) Baseline review of the status and management of the Caribbean spiny lobster fisheries in the CARICOM region. CRFM, Belize City

Cruz R, Bertelsen RD (2009) The spiny lobster (Panulirus argus) in the wider Caribbean: a review of life cycle dy- namics and implications for responsible fisheries management. Proc Gulf Caribb Fish Inst 61:433-446

Dávila D, Cruz R, Sanz A, Perera E, Saavedra G (2009a) Histología gonadal de la langosta Panulirus argus. 1. Hembras. Rev Investig Mar 30:215-225

Dávila D, Cruz R, Sanz A, Perera E, Saavedra G (2009b) Histología gonadal de la langosta Panulirus argus. 2. Machos. Rev Investig Mar 30:227-236

*Davis GE (1975) Minimum size of mature spiny lobsters, Panulirus argus, at Dry Tortugas, Florida. Trans Am Fish Soc 104:675-676

de Lestang S, Hall NG, Potter IC (2003) Reproductive biology of the blue swimmer crab (Portunus pelagicus, Decapoda: Portunidae) in five bodies of water on the west coast of Australia. Fish Bull 101:745-757

Evans CR, Lockwood APM, Evans AJ, Free E (1995) Field studies of the reproductive biology of the spiny lobsters Panulirus argus (Latreille) and P. guttatus (Latreille) at Bermuda. J Shellfish Res 14:371-381

FAO (1968) Report to the Government of British Honduras (Belize City) on investigations into marine fisheries, particularly spiny lobster and shrimp resources. Based on the work of D. Weber, FAO/TA Marine Fishery Biologist. Rep TA 2541. FAO, Rome

FAO (2001) Report on the FAO/DANIDA/CFRAMP/ WECAFC regional workshops on the assessment of the Caribbean spiny lobster (Panulirus argus). FAO, Rome

FAO (2014) Western Central Atlantic Fishery Commission Report of the first meeting of the OSPESCA/WECAFC/ CRFM/CFMC Working group on Caribbean spiny lobster. FAO Fisheries and Aquaculture Report SLC/FIPS/ SLM/R1095 (Bi). FAO, Rome

FAO (2019) Caribbean spiny lobster (Panulirus argus) fishery regional management plan. Western Central Atlantic Fisheries Commission $17^{\text {th }}$ Session. WECAFC/XVII/ 2019/10. FAO, Rome

FAO/WECAFC (2018) The regional Caribbean spiny lobster (Panulirus argus) fishery management plan. Ninth Session of the Scientific Advisory Group. WECAFC/SAG/ IX/2018/6. FAO, Rome

Flores A, Wiff R, Díaz E (2015) Using the gonadosomatic index to estimate the maturity ogive: application to Chilean hake (Merluccius gayi gayi). ICES J Mar Sci 72:508-514

Freeman MA, Turnbull JF, Yeomas WE, Bean CW (2010) Prospects for management strategies of invasive crayfish populations with an emphasis on biological control. Aquat Conserv 20:211-223

Gardner C, Mills D, Frusher S (2005) Does pleopod setation provide a measure of maturity in female southern rock lobsters Jasus edwardsii? Sci Mar 69:123-131

Gascoigne J, Matthews T, Groeneveld J (2018) The Bahamas spiny lobster fishery. Marine Stewardship Council, London

Firaldes BW, Smyth DM (2016) Recognizing Panulirus meripurpuratus sp. nov. (Decapoda: Palinuridae) in BrazilSystematic and biogeographic overview of Panulirus species in the Atlantic Ocean. Zootaxa 4107:353-366

* Gnanalingam G, Butler MJ IV, Matthews TR, Hutchinson E, Kilada R (2019) Directly ageing the Caribbean spiny lobster, Panulirus argus with validated band counts from gastric mill ossicles. ICES J Mar Sci 76:442-451

Goñi R, Quetglas A, Reñones O (2003) Size at maturity, fecundity and reproductive potential of a protected population of the spiny lobster Palinurus elephas (Fabricius, 
1787) from the western Mediterranean. Mar Biol 143: 583-592

Gregory DR, Labisky RF (1981) Ovigerous setae as an indicator of reproductive maturity in the spiny lobster, Panulirus argus (Latreille). Northeast Gulf Sci 4:109-113

Haarr ML, Sainte-Marie B, Comeau M, Tremblay MJ, Rochette R (2018) Female American lobster (Homarus americanus) size-at-maturity declined in Canada during the 20th and early 21st centuries. Can J Fish Aquat Sci 75:908-924

Hamasaki K, Sugiyama A, Jinbo T, Murakami K (2018) The influence of male size on competitive mating success in the Japanese spiny lobster Panulirus japonicus (von Siebold, 1824) (Decapoda: Palinuridae): implications for broodstock management techniques. J Crustac Biol 38:393-400

Holthius LB (1991) FAO species catalogue, Vol 13. Marine lobsters of the world. An annotated and illustrated catalogue of species of interest to fisheries to date. FAO Fish Synop No. 125. FAO, Rome

Horsford I, Simon H, Archibald M, Webber J, Joseph T (2014) Biology, status, and current management of the Caribbean spiny lobster (Panulirus argus). Proc Gulf Caribb Fish Inst 66:423-433

Jayakody DS (1989) Size at onset of sexual maturity and onset of spawning in female Panulirus homarus (Crustacea: Decapoda: Palinuridae) in Sri Lanka. Mar Ecol Prog Ser 57:83-87

Joshi PC, Khanna SS (1982) Seasonal changes in the ovary of a freshwater crab, Potamon koolooense (Rathbun). Proc Indiana Acad Sci Anim Sci 91:451-462

Juinio MAR (1987) Some aspects of the reproduction of Panulirus penicillatus (Decapoda: Palinuridae). Bull Mar Sci 41:242-252

Kelly R (2002) Report on the spiny lobster fishery in Jamaica. In: Report of the second workshop on the management of Caribbean spiny lobster fisheries in the WECAFC area Havana, Cuba, 30 September-4 October 2002. FAO Fisheries Report No. 715. FAO, Rome

Kizhakudan JK, Radhakrishnan EV, Pillai SL (2019) Reproductive biology of spiny and slipper lobster. In: Radhakrishnan EV, Phillips BF, Achamveetil G (eds) Lobsters: biology, fisheries and aquaculture. Springer, Singapore, p 363-408

Kough AS, Paris CB, Butler MJ IV (2013) Larval connectivity and the international management of fisheries. PLOS ONE 8:e64970

Kulmiye AJ, Mavuti KM, Groeneveld JC (2006) Size at onset of maturity of spiny lobsters Panulirus homarus homarus at Mambrui, Kenya. Afr J Mar Sci 28:51-55

Landers DF Jr, Keser M, Saila SB (2001) Changes in female lobster (Homarus americanus) size at maturity and implications for the lobster resource in Long Island Sound, Connecticut. Mar Freshw Res 52:1283-1290

* Le Bris A, Pershing AJ, Gaudette J, Pugh TL, Reardon KM (2017) Multi-scale quantification of the effects of temperature on size at maturity in the American lobster (Homarus americanus). Fish Res 186:397-406

Linnane AJ, Penny SS, Ward TM (2008) Contrasting fecundity, size at maturity and reproductive potential of southern rock lobster Jasus edwardsii in two South Australian fishing regions. J Mar Biol 88:583-589

Little SA, Watson WH III (2003) Size at maturity of female American lobsters from an estuarine and coastal population. J Shellfish Res 22:857-863
Little SA, Watson WH III (2005) Differences in the size at maturity of female American lobsters, Homarus americanus, captured throughout the range of the offshore fishery. J Crustac Biol 25:585-592

MacFarlane JW, Moore R (1986) Reproduction of the ornate rock lobster, Panulirus ornatus (Fabricius), in Papua New Guinea. Aust J Mar Freshw Res 37:55-65

*Maxwell KE, Matthews TR, Sheehy MR, Bertelsen RD, Derby CD (2007) Neurolipofuscin is a measure of age in Panulirus argus, the Caribbean spiny lobster, in Florida. Biol Bull (Woods Hole) 213:55-66

* Maxwell KE, Matthews TR, Bertelsen RD, Derby CD (2009) Using age to evaluate reproduction in Caribbean spiny lobster, Panulirus argus, in the Florida Keys and Dry Tortugas, United States. NZ J Mar Freshw Res 43:139-149

* McLeay LJ, Doubell MJ, Linnane AJ (2019) Spatial and temporal variations in female size at maturity of a southern rock lobster (Jasus edwardsii) population: a likely response to climate change. PLOS ONE 14:e0225144

* McPherson LR, Ganias K, Marshall CT (2011) Inaccuracies in routinely collected Atlantic herring (Clupea harengus) maturity data and correction using a gonadosomatic index model. J Mar Biol Assoc UK 91:1477-1487

*Melville-Smith R, de Lestang S (2005) Visual assessment of the reproductive condition of female western rock lobsters (Panulirus cygnus). NZ J Mar Freshw Res 39: $557-562$

*Melville-Smith R, de Lestang S (2006) Spatial and temporal variation in the size at maturity of the western rock lobster Panulirus cygnus George. Mar Biol 150:183-195

Melville-Smith R, de Lestang S, Johnston D (2010) Higher water temperature leads to precocious maturation of western rock lobsters (Panulirus cygnus), but are things that simple? J Mar Biol Assoc India 52:257-263

*Minagawa M (1999) Quantitative analysis of the seasonality of male reproduction in the spiny lobster Panulirus japonicus (Decapoda: Palinuridae). J Crustac Biol 19: 276-282

*Minagawa M, Higuchi S (1997) Analysis of size, gonadal maturation, and functional maturity in the spiny lobster Panulirus japonicus (Decapoda: Palinuridae). J Crustac Biol 17:70-80

*Minagawa M, Sano M (1997) Oogenesis and ovarian development cycle of the spiny lobster Panulirus japonicus (Decapoda: Palinuridae). Mar Freshw Res 48:875-887

Mota Alves MI, Tome GS (1965) On the histological structure of the gonads of Panulirus argus (Latr.). Arq Cienc Mar 5:15-26

Munro JL (1974) The biology, ecology and bionomics of spiny lobsters (Palinuridae), spider crabs (Majiidae) and other crustacean resources. In: Munro JL (ed) The biology, ecology, exploitation and management of Caribbean reef fishes. Scientific Report of the ODA/UWI Fisheries Ecology Research Project 1969-1973. University of the West Indies, Jamaica. International Center for Living Aquatic Resources Management, Manila, p 206-222

\%̈̈ndes F, Kaiser MJ, Murray LG (2017) Relative growth and size at onset of sexual maturity of the brown crab, Cancer pagurus in the Isle of Man, Irish Sea. Mar Biol Res 13:237-245

Peacock NA (1974) A study of the spiny lobster fishery of Antigua and Barbuda. Proc Gulf Caribb Fish Inst 26: $117-130$

Pereira G, Josupeit H (2017) The world lobster market. FAO Globefish Research Programme Vol 123. FAO, Rome 
Pérez-González R, Puga-López D, Castro-Longoria R (2009) Ovarian development and size at sexual maturity of the Mexican spiny lobster Panulirus inflatus. NZ J Mar Freshw Res 43:163-172

Pollock DE (1995) Changes in maturation ages and sizes in crustacean and fish populations. S Afr J Mar Sci 15:99-103

Puga R, Piñeiro R, Cobas LS, de León ME, Capetillo N, Alzugaray R (2010) La pesquería de la langosta espinosa, conectividad y cambio climático en Cuba. In: HernándezZanuy A, Alcolado PM (eds) La Biodiversidad en ecosistemas marinos y costeros del litoral de iberomamérica y el cambio climático: I. Memorias del Primer Taller de la Red CYTED BIODIVMAR. Instituto de Oceanología, La Habana, p 112-131

R Core Team (2020) R: a language and environment for statistical computing. R Foundation for Statistical Computing, Vienna

Riveros-Celis G (1972) Spiny lobster Panulirus argus and Panulirus laevicauda (Latreille) on the Caribbean coast of Columbia with particular references to their biology and the fisheries for both species on the coast of the Guajira Peninsula. MSc thesis, Memorial University of Newfoundland, St. John's

Sabrah MM, Heneish RA, Alwany ME, Ahmad MI (2017) Sexual maturity, spawning activity, sex ratio and fecundity of two Mullidae species dwelling the Gulf of Suez, Red Sea. Egypt J Aquat Res 43:83-91

Sarver SK, Silberman JD, Walsh PJ (1998) Mitochondrial DNA sequence evidence supporting the recognition of two subspecies or species of the Florida spiny lobster Panulirus argus. J Crustac Biol 18:177-186

Silva JRF, Da Cruz-Landim C (2006) Macroscopic aspects and scanning electron microscopy of the ovaries of the spiny lobsters Panulirus (Crustacea: Decapoda). Braz J Morphol Sci 23:479-486

Editorial responsibility: Stephen Wing

Dunedin, New Zealand

Reviewed by: N. Brown-Peterson, D. Bögner and

1 anonymous referee
Sørdalen TK, Halvorsen KT, Harrison HB, Ellis CD and others (2018) Harvesting changes mating behaviour in European lobster. Evol Appl 11:963-977

Sutcliffe WH Jr (1952) Some observations on the breeding and migration of the Bermuda spiny lobster, Panulirus argus. Proc Gulf Caribb Fish Inst 4:64-69

* Tewfik A, Babcock EA, Phillips M (2020) Spiny lobster fisheries status across time and a mosaic of spatial management regimes. ICES J Mar Sci 77:1002-1016

* Thangaraja R, Radhakrishnan EV (2017) Reproductive biology and size at onset of sexual maturity of the spiny lobster Panulirus homarus homarus (Linnaeus, 1758) in Khadiyapatnam, southwest coast of India. J Mar Biol Assoc India 59(2):19-28

Trott T, Luckhurst BE, Medley P (2002) Report of the Second Workshop on the Management of Caribbean Spiny Lobster Fisheries in the WECAFC Area Havana, Cuba. FAO Fish Rep 715. Western Central Atlantic Fishery Commission. FAO, Rome

*Truelove NK, Ley-Cooper K, Segura-García I, BrionesFourzán P and others (2015) Genetic analysis reveals temporal population structure in Caribbean spiny lobster (Panulirus argus) within marine protected areas in Mexico. Fish Res 172:44-49

* Tu CY, Chen KT, Hsieh C (2018) Fishing and temperature effects on the size structure of exploited fish stocks. Sci Rep 8:7132

Waiho K, Fazhan H, Ikhwanuddin M (2016) Size distribution, length-weight relationship and size at the onset of sexual maturity of the orange mud crab, Scylla olivacea, in Malaysian waters. Mar Biol Res 12: 726-738

Wilkin RM, Goodwin MH, Waugh GT (1986) Spiny lobster management program in St. Kitts/Nevis. Proc Gulf Caribb Fish Inst 37:87-90

Submitted: November 18, 2020

Accepted: May 19, 2021

Proofs received from author(s): July 20, 2021 